\title{
Otolaryngologic Manifestations Among Hiv/Aids Patients in a Nigerian Tertiary Health Institution: An Update
}

\section{Manifestações Otorrinolaringológicas entre Pacientes com HIV / AIDS em Instituição de Saúde Terciária da Nigéria: Uma Atualização}

\author{
Dr. ALabi Biodun Sulyman*, Dr. Salami Alakija Kazeem**, Dr. Afolabi Abdulrabman***, \\ Dr. Dunmade David ${ }^{* * *}$, Aremu Shuaib Kayode*****, Olawunmi Oluwayemisi******, \\ Akande Halima Jumai******, Odeigha L O*******.
}

\footnotetext{
* DR (Senior Lecturer \& Consultant Ent, Head \& Neck Surgeon).

** Dr (Reader in Pulmonolgy and Infectitious Disease, Dept of Medicine, University of Ilorin Teaching Hospital, Ilorin, Kwara State. Nigeria).

**** Consultant ENT Surgeon, Dept of Ent, University of Ilorin Teaching Hospital, Ilorin, Nigeria (Consultant ent surgeon).

***** Dr (Senior Lecturer \& Consultant Ent Surgeon, Dept of Ent, UITH, Ilorin, Nigeria).

****** DR (Post Fellowship Senior Registrar, Dept of Ent, UITH, Ilorin, Nigeria).

******* Dr (Senior Lecturer \& Consultant Haematologist, Dept of Haematology, UITH, Ilorin, Nigeria)

********* Dr (Lecturer and Consultant Radiologist, Dept of Radiology, UITH, Ilorin, Nigeria).

********* Dr (Consultant Family Physician, Dept of Family Medicine, UITH, Ilorin, Nigeria)
}

Institution: Dept of Ent, College of Health Sciences, University of Ilorin Teaching Hospital, Ilorin, Kwara State. Nigeria.

Mail address: Dr. B. S. Alabi, Senior Lecturer, Dept of Ent, College of Health Sciences, University of Ilorin Teaching Hospital, Ilorin, Box 4210, Zip code 240001, Ilorin, Nigeria - Telephone: +2348033465653 - E-mail: alabibs@yahoo.com

Article received in June 6, 2010. Article approved in July 7, 2010

\section{RESUMO}

Introdução / Objetivo: Este estudo é determinar essas manifestações de pacientes com HIV / AIDS em Ilorin para atualizar no estudo anterior.

Método:

Este foi um estudo prospectivo de todos os pacientes consecutivos novo confirmado para ser HIV positivo atendidos na clínica de HIV da Universidade de Ilorin Hospital, Ilorin, no estado de Kwara, na Nigéria, entre janeiro e julho de 2009. These estavam em anti HAART tratamento de drogas retrovirais. As informações recuperadas incluído o de dados biográficos, apresentação clínica, otorrinolaringológicas achados clínicos, bem como a sua avaliação da audição com audiometria tonal.

Resultados:

74 fora dos 89 pacientes HIV (82,8 \%) apresentaram manifestações otorrinolaringológicas com a faixa etária de 3 a 62 anos (média de 36.4 anos, DP = 2,45 \pm 0,02). A faixa etária modal era de 2140 anos (59,6\%) 51 masculinos. (57,3\%) e 38females (42,7\%) e razão sexual de 1,3:1. Apresenta os mais comuns otorrinolaringológico incluíram nasal em 45,6\% (rinossinusite crônica), adenopatia oral / orofaringe em 23,9\% (candidíase oral), otológica em 21,5\% (otite média serosa) e cervical em $9 \%$.

Conclusão:

As manifestações otorrinolaringológicas foram encontrados em 74 pacientes (82,8\%) e as características comuns sinusite crônica, oral / candidíase faringe, otite média serosa com adeopathy cervical, nessa ordem. É importante para os otorrinos estar ciente das manifestações otorrinolaringológicas, assim que o diagnóstico precoce e intervenção atempada junto com terapia anti- retroviral adequado ser instituído para melhorar as taxas de sobrevivência

Palavras-chave: sinusite, otite média com efusão, candidíase bucal, HIV.

\section{SUMMARY}

Introduction/Aim: Method:

This study is to determine these manifestations among HIV/AIDS patients in Ilorin to update on previous study. This was a prospective study of all consecutive new patients confirmed to be HIV positive attending the HIV clinic of the University of Ilorin Teaching Hospital, Ilorin, Kwara state, Nigeria between January and July, 2009. These patients were on HAART anti retroviral drug treatment. The information retrieved included the biodata, clinical presentation, otolaryngologic clinical findings, as well as their hearing assessment with Pure tone audiometry.

Results: 74 out of the 89 HIV patients $(82.8 \%$ ) had otorhinolaryngological manifestations with the age range of 3 to 62 years (Mean of $36.4 \mathrm{yrs}, \mathrm{SD}=2.45 \pm 0.02$ ). The modal age range was $21-40$ years (59.6\%) 51 males (57.3\%) and 38 females (42.7\%) and a sex ratio of 1.3:1. Commonest otorhinolaryngological features included nasal in $45.6 \%$ (chronic rhinosinusitis), oral/oropharyngeal in 23.9\% (oral candidiasis), otological in $21.5 \%$ (Serous otitis media) and cervical adenopathy in $9 \%$.

Conclusion: Otorhinolaryngological manifestations were found in 74 patients (82.8\%) and commonest features included chronic sinusitis, oral/pharyngeal candidiasis, serous otitis media with cervical adeopathy in that order. It is important for otolaryngologists to be aware of otolaryngological manifestations, so early diagnosis and timely intervention alongside appropriate anti-retroviral therapy be instituted to improve survival rates.

Keywords: sinusitis, otitis media with effusion, candidiasis oral, HIV. 


\section{INTRODUCTION}

HIV infection is a global pandemic, with an estimated 42 million among adults worldwide, two thirds of who are in sub-Saharan Africa; $47 \%$ of cases are women and an estimated 1.3 million children less than 15 years of age (1). The reported prevalence of ENT, head and neck manifestations of HIV/AIDS worldwide varies from 41 to $80 \%(2,3,4,5)$.

In the United States, HIV sero-prevalence varied between $0.45 \%-27.5 \%$ while it is $1.2 \%-12 \%$ in Nigeria (6, 7). HIV preferentially infects cells of the nervous and lymphatic systems. The most important cell infected is the T-helper cell, through the CD 4 receptor, resulting in both functional impairment and numeric depletion of $\mathrm{T}$ helper cells. The transmission of the virus occurs through blood and its products, sexual contacts, transplacentally in utero and via breast feeding (8).

The causes of ORL manifestations are due to infections, neoplasms and primary neurological damage resulting from the HIV (9).

This study is to reappraise these features among HIV/AIDS patients after a preliminary study done among 29 patients at our centre over five years ago (10).

\section{METHOD}

This was a prospective study of all consecutive new patients confirmed to be HIV positive using the ELISA technique with confirmation by the Western blot assays attending the HIV clinic of the University of Ilorin Teaching Hospital, Ilorin, Kwara state, Nigeria between January and July, 2009. These patients were on HAART anti retroviral drug treatment.

Informed consents from individual patient and ethical approvals were obtained from the hospital authority. The information retrieved included the biodata, clinical presentation, otolaryngologic clinical findings, as well as their hearing assessment with Pure tone audiometry (using clinical diagnostic audiometer Madsen OB 822, Denmark calibrated according to ISI). Patients with inadequate records were excluded from analysis. Data were entered into the computers and analysed with EPI INFO 2005 version 3.

\section{RESULTS}

A total of 100 patients were seen over the study period but 89 patients had complete data for analysis.
Table I. Age disribution of HIV patients

\begin{tabular}{lcc}
\hline Age range & Frequency & Percentage $(\%)$ \\
\hline >20yrs & 2 & 2.2 \\
$21-39 y r s$ & 53 & 59.6 \\
$40-64 y$ rs & 34 & 38.2 \\
$\geq 65 y r s$ & 0 & 0 \\
\hline Total & 89 & 100 \\
\hline
\end{tabular}

Table 2. Occupational distribution among HIV/AIDS patients.

\begin{tabular}{lcc}
\hline Occupation & Frequency & Percentage $(\%)$ \\
\hline Civil servant & 12 & 13.5 \\
Artisan & 12 & 13.5 \\
Farming & 2 & 2.3 \\
Selfemployed & 44 & 49.4 \\
Unemployed & 14 & 15.6 \\
Security/force & 3 & 3.4 \\
Pensioner & 2 & 2.3 \\
\hline Total & 89 & 100 \\
\hline
\end{tabular}

There were 51 males (57.3\%) and 38 females (42.7\%) with a sex ratio of 1.3:1. The age range was 3 to 62 years (Mean of $36.4 \mathrm{yrs}, \mathrm{SD}=2.45 \pm 0.02$ ). The modal age range was 21 40years (59.6\%), followed by 41 to 60(36\%) and over sixty and below twenty years were $2(2.2 \%)$ each (Table 1 ).

Majority of the patients 44 (49.4\%) were self employed, 14 (15.6\%) were unemployed, 12 (13.5\%) were civil servants and artisans, 3 (3.4\%) were security forces and 2 (2.3\%) each were either farmers or pensioners (Table 2). Seventy-six (85.4\%) of the respondents were married while $8(9 \%)$ were single, $4(4.5 \%)$ were widowed and only one (1.1\%) was divorced. History of smoking was found only among $18 \%$ of the respondent while 73 (82\%) do not smoke and 19 (21.3\%) take alcohol.

The risk factors for HIV transmission included heterosexual contacts in $90 \%$ of cases, blood transfusions in 5\% and others were $5 \%$. The average period between diagnosis and commencement of anti-retroviral drugs is 3 to 6 months.

Relating to otorhinological symptoms, otological symptoms included 9 (10.1\%) with hearing loss, 14(15.7\%) cases of tinnitus and vertigo each, 12 (13.5\%) with ear blockage and $13(14.6 \%)$ with otalgia (Table 3).

Pharyngeal symptoms included 40 (44.9\%) with oral/oropharyngeal candidiasis, 18 (20.2\%) with recurrent aphthous ulcers and 11 (12.4\%) with dysphagia and odynophagia. 
Nasal symptoms included nasal blockage in 19 (24.3\%), 10 (11.2\%) had history of epistaxis, 25 (30.3\%) with anosmia, 58 (65.2\%) had recurrent nasal discharge (catarrh) (65.8\%), 30 (33.7\%) had recurrent sneezing, 4 (4.5\%) with snoring (Table 3). Cervical swellings occured in $30(33.7 \%)$ patients, other constitutional symptoms occurred in 42 patients.

The duration of diagnosis ranged from 1 week to 13 yrs with the modal duration of less than 2 yrs. 68 (76.4\%) of the respondents have commenced antiretroviral drugs which ranged from less than 3 months to over 12 months. Ear examination revealed 11 had wax impaction in either of the ears, $1(1.1 \%)$ with otomycosis, one with chronic suppurative otitis media, but evidence of serous otitis media (glue ear) in 58 (65.1\%) but there was no evidence of Ramsay-Hunt syndrome.

Pure tone audiometry showed conductive hearing loss (CHL) in 20 (22.5\%) on the right and 30 (33.7\%) on the left ears, sensori-neural (SNHL) in $9(10.1 \%)$ on the right, $7(7.9 \%)$ on the left, mixed hearing loss $8(9 \%)$ on the right, $7(7.9 \%)$ on the left (Table 4). Categorization of degree of hearing showed normal hearing in 15 (16.9\%) on the right, $11(12.4 \%)$ on the left, mild hearing loss in $22(24.7 \%)$ on the right, 24 (27\%) on the left, moderate hearing loss in 32 (36\%) on the right, $38(42.7 \%)$ on the left, moderatelysevere hearing in $19(21.3 \%)$ on the right, $16(18 \%)$ on the left, severe hearing loss only in 1 (1.1\%) right ear. The nasal examination revealed engorged inferior turbinates on anterior rhinoscopy in $82(92.1 \%)$ of the patients, oropharyngeal examination revealed amputated uvula in 14 (15.7\%), hypertrophied and atrophied tonsils in 3 (3.4\%) and 9 (10.1\%) patients respectively. There was evidence of chronic pharyngitis (granular posterior pharyngeal wall) in $74(83.1 \%)$, hyperaemia in 4 (4.5\%) and normal in $11(12.4 \%)$ patients.

\section{DisCussion}

Since the infective agent responsible for HIV/AIDS was discovered in 1983, the spectrum of manifestations has become well defined with nearly $84 \%$ of infected individuals having otorhinolaryngological symptoms or signs (11). Various studies reported varied prevalences, Marusann and Soy (6), in their study of 399 patients with AIDS, found that 165 (41\%) had symptoms related to otolaryngology. Williams (12), in his study of 50 patients with diagnosis of pediatric AIDS, reported otolaryngological manifestation to occur in more than $80 \%$ of patients. Chandra Prasad et al reported a prevalence of $79 \%$ among 968 patients with HIV (13), earlier report by AlaBI et al in Ilorin, Nigeria (2004) reported a prevalence of $78 \%$ among 29 patients (10).
Table 3 A. Otorhinolaryngological manifestaions among HIV/AIDS patients : Symptoms

\begin{tabular}{lr}
\hline Symptoms & Frequency \\
\hline Otological & $9(10.1 \%)$ \\
Hearing loss & $\mid 4(15.7 \%)$ \\
Tinnitus & $14(15.7 \%)$ \\
Vertigo & $12(13.5 \%)$ \\
Earblockage & $13(14.6 \%)$ \\
Otalgia & $3(3.4 \%)$ \\
Otitis Externa & $6(6.7 \%)$ \\
Hearingimpairment & 71 \\
\hline Total & \\
\hline Nasal & $19(21.3 \%)$ \\
$\quad$ Nasal blockage & $10(11.4 \%)$ \\
$\quad$ Epistaxis Nose bleeds) & $58(65.2 \%)$ \\
Recurrent nasal discharge & $35(39.3 \%)$ \\
Sneezing & $25(30.3 \%)$ \\
$\quad$ Anosmia & $4(4.5 \%)$ \\
Snoring & $|5|$
\end{tabular}

Table 3B

Oral/Oropharyngeal

Recurrentaphthous ulcers 28 (20.2\%)

Dysphagia/odynophagia I I (12.4\%)

Oral candidiasis $\quad 40$ (44.9\%)

\begin{tabular}{lll}
\hline Total & 79 \\
\hline Neck(Cervical) Swellings & 30 & $(33.7 \%)$ \\
Other constitutional symptoms & 42 & $(47.2 \%)$ \\
Cough/weight loss/anorexia/diarrhoea & \\
\hline
\end{tabular}

Table 4. Pure tone audiometric outcome among HIV patients.

\begin{tabular}{lcc}
\hline & $\begin{array}{c}\text { Frequency } \\
\text { Right }\end{array}$ & $\begin{array}{c}\text { Frequency } \\
\text { Left }\end{array}$ \\
\hline Conductive hearing loss $(\mathrm{CHL})$ & $24(27 \%)$ & $33(37.1 \%)$ \\
Mixed hearing loss & $8(9.0 \%)$ & $7(7.9 \%)$ \\
Sensori-neural hearing loss(CHL) & I3( $14.6 \%)$ & $1 \mid(12.4 \%)$ \\
Normal hearing & I $5(16.9 \%)$ & $1 \mid(12.4 \%)$ \\
\hline Total & $89(100 \%)$ \\
\hline
\end{tabular}

Although the ENT manifestations in this population (82.8\%) are certainly higher than in the general population, not all of them could be solely attributed to the HIV seropositiveness. It is known that HIV infections are generally symptomless and once AIDS is established this figure changes dramatically.

The modal age of between 21-39 yr which differ from other studies with age range 20-49 yrs (14) still fall 
within age group found by most studies; however our study found a lower value compared to somefun et al in Nigeria and a lower age group of 3 yrs which was limited to few studies $(15,16)$. Our study showed a higher prevalence among the males compared to the females which is similar to most studies in different part of the world (3-6, 17, 18).

Majority of the patients were self employed in $49.4 \%$ most of whom are involved in trading and small scale business followed by unemployed, this indicated that HIV is still most prevalent among the lower socio-economic class similar to a study in some parts of Africa (14).

The study showed that more than three-quarter of the respondents were married but this does not indicate the source of the infection with the least among the divorcee, most studies does not highlight the marital status of the respondents. Incidence of alcohol ingestion and smoking have been found to be very low among the respondents which most literatures are silent about as it is not a high risk and majority of those involved in the habit of either smoking or alcohol consumptions have been doing so for between 6 months to 20 yrs duration.

Chronic rhinosinusitis was found to be the commonest manifestation in our series, evidenced by clinical presentation of recurrent nasal discharge and obstruction, sneezing,epistaxis, supported by the examination findings of engorged turbinate which is similar to findings in other part of the world $(11,12,19,20)$. Rhinosinusitis is common in HIV-infected patients, with a reported prevalence between $20 \%$ and $68 \%$ (21). The reasons adduced included changes in the mucociliary clearance, a primary local defense mechanism for the sinuses. The bacteriology of acute sinusitis in this population includes the same organisms normally considered in the immunocompetent patient however, In late stages of HIV infection, atypical opportunistic fungal sinusitis is the rule.

Oral and oropharyngeal symptoms were the second commonest in our study with oral candidiasis and recurrent sore throat with aphthous ulcers being the commonest oropharyngeal symptoms, this is similar to studies in other part of the world that found oropharyngeal candidiasis to be the commonest presentations $(18,22)$.

The commonest otological symptoms were tinnitus and vertigo in $15.7 \%$ each followed by otalgia and ear blockage in $14.6 \%$ and $13.5 \%$ respectively, the least was hearing loss of which serous otitis media was the commonest. The most common otologic problems reported in HIVinfected patients are serous otitis media due usually to eustachian tube dysfunction and recurrent acute otitis media (23).
Eustachian tube dysfunction can result from nasopharyngeal lymphoid hyperplasia, sinusitis, nasopharyngeal neoplasms, or allergies and their associated mucosal changes. This is at variance with study in other part of the world that reported sudden sensorineural hearing loss, chronic and recurrent otitis media to be the commonest otological manifestation $(17,18,19)$, tympanic membrane perforation in only one of the respondent this is an unusual finding compared to other studies where chronic otitis media was one of the commonest ENT findings and may also be a hallmark in some reports $(13,17)$. Audiological evaluations showed conductive hearing loss in $27-37 \%$ of the respondents, sensorineural in $12-14.6 \%$ while normal hearing was found only among $12-17 \%$ of the respondents this was at variance with study done by somefun et al who found sensorineural hearing loss to be the commonest (5) although the pure tone audiometry is a subjective test but it has been supported by earlier clinical findings.

Other studies elsewhere have reported that most otological problems are caused by routine organisms that respond to standard therapy (4) or may be as a result of direct consequence of virus or secondary to the pharmacological treatment (21). The cause of the hearing loss cannot be substantiated by our study as the hearing assessment was not done before the commencement of the anti-retroviral drugs which is an area of challenge to focus in future studies to compare the hearing assessment before and after commencement of anti-retroviral therapies.

Due to the involvement of central nervous system in HIV infection, the most direct consequence to the auditory system is central auditory nervous system abnormalities similar extrapolation can be drawn to the effect on the olfactory nerve of smell as it affects almost one-third of the respondents (24). Cervical adenopathy was the fourth commonest, however other studies have found cervical manifestation to be the most frequent symptoms of presentation (25-29). There was no either Kaposi sarcoma or non Hodgkin's lymphoma in our series as compared to study in the developed world

\section{CONCLUSION}

In conclusion, ENT manifestation of HIV occurred in over four-fifth of the patients with leading features of chronic rhinosinusitis, oropharyngeal candidiasis,serous otitis media and cervical adenopathy.Often, the otolaryngologist is the primary physician who diagnoses the HIV infection. He should be aware and vigilant for its symptoms and unusual presentations. With more people coming forward for voluntary counselling and testing for HIV, it is important for otolaryngologists to be aware of otolaryngological 
manifestations so early diagnosis and timely intervention alongside appropriate anti-retroviral therapy be instituted to improve survival rates.

\section{REFERENCES}

1. Table of country-specific HIV/AIDS estimates and data, end 2003. In: S. Woods, Editor, UNAIDS 2004 Report on the Global HIV/AIDS Epidemic: 4th global report. UNAIDS/ 04.16E. June (2004), 190-206.

2. Sorvino D, Lucente FE. Acquired immunodeficiency syndrome-the epidemic. Otolaryngol Clin North Am. 1992, 25(6):1147-1158.

3. Riederer AP, Grein GO and Bogner JR. High prevalence of opportunistic infections in the head and neck related to human immunodeficiency of otorhinolaryngologic disorders in 250 patients. Infection. 1996, 24(6):440-446.

4. Williams MA. Head and neck findings in pediatric acquired immune deficiency syndrome. Laryngoscope. 1987, 97:713-6.

5. Somefun A, Nwawolo CC, Okeowo PA, Ogban LU, Akanmu AS, Okanny CC, Akinsete I. Otorhinolaryngological manifestations of HIV/AIDS in Lagos. Niger Postgrad Med J. 2001, 8(4):170-4.

6. Lalwani AK, Sooy CD. Otologic and neurotologic manifestations of acquired immunodeficiency syndrome. Otolaryngol Clin North Am. 1992, 25:1183-1197.

7. Federal Ministry of Health. National AIDS/STD control programme. 1999 HIV/ Syphillis sentinel seroprevalence survey in Nigeria. Technical report with HIV infection. J Gen Intern Med. 1991, 6:S19-S23.

8. Scheiber E, Sculpilliti F. HIV infection and ear,nose and throat symptoms: XVI World Congress of ORL, Head and Neck Surgery. 1997, 10:629-638.

9. Kelvin CL, Thomas AT. Otolaryngological Manifestations of HIV, HIV InSite Knowledge Base Chapter, HIV Insite. 1998:1-28.

10. Alabi BS, Dunmade AD. Otolaryngologic manifestations among hiv/aids patients in a nigerian tertiary health institution - A preliminary Study. Sahel Medical Journal. 2006, 9(3):8285.

11. Jolles S, Kinloch de Loes S, and Johnson MA et al. Primary HIV-1 infection: a new medical emergency, BMJ. 1996, 312:1243-1244.
12. Marcusen CD and Sooy CD. Otolaryngologic and head and neck manifestations of AIDS. Laryngoscope. 1985, 95:401-405.

13. Prasad CK, Bhojwani KM, Vijendra Shenoy V, Prasad SC. HIV manifestations in Otolaryngology. AmJ Otolaryngology. 2006, 27(3):179-185.

14. Vignikin-Yehouessi B, Gomina M, Adjibabi W, Biotchane I, Vodouhe SJ, Hounkpe Y, Medji A. HIV and ENT Manifestations: epidemiologic and clinic aspects at CNHU of Cotonou and CHD Oueme-Plateau. Mali Med. 2006;21(2):31-34.

15. Sacko HB, Ag Mohamed A, Maiga MY, Kalle A, Doumbia SY, Guindo A. ORL manifestations observed in AIDS. Apropos of 65 cases. Bull Soc Pathol Exot. 1995, 88(5):234-5.

16. Chidzonga MM. HIV/AIDS orofacial lesions in 156 Zimbabwean patients at referral oral and maxillofacial surgical clinics. Oral Dis. 2003, 9(6):317-22.

17. OConnor AF. Examination of the ear. In: Kerr AG, Booth JB, eds. Scott Browns Otolaryngology: Otology. 6th Ed. Oxford (UK): Butterwortb/Heineman; 1997:3/1/1-3/1/29.

18. Deb T, Singh NB, Devi HP Sanasam JC, Head and Neck Manifestation of HIV infection: a preliminary study. J Indian Med Assoc. 2003, 101:93-5.

19. Vignikin-Yehouessi B, Gomina M, Adjibabi W, Biotchane I, Vodouhe SJ, Hounkpe Y, Medji A. HIV and ENT Manifestations: epidemiologic and clinic aspects at CNHU of Cotonou and CHD Oueme-Plateau. Mali Med. 2006, 21(2):31-34.

20. Lasisi AO. Otolaryngological Manifestations of HIV/ AIDS Annals of Ibadan Postgraduate Medicine. 2005 3(1):33-39.

21. Rubin JS. Honigsberg R. Sinusitis in patients with the acquired immunodeficiency syndrome. Ear Nose Throat J. 1990, 69:460-463.

22. Zambetti G, Luce M, Ciofalo A, Leonardi M, Filiaci F. Otorhinolaryngological aspects of HIV infections: personal experience. Allergol Immunopathol (Madr). 1994, 22(5):192-6.

23. Kohan D, Rothstein SG, Cohen NL. Otologic disease in patients with acquired immunodeficiency syndrome. Ann Otol Rhinol Laryngol. 1988, 97:636-640.

24. Solanellas Soler J, Soldado Patino L, Losano De Leon F. Sudden hearing loss and HIV infection. Acta Otorrinolarringol Esp. 1996, 47:311-3. 
25. Ranjan R, Bhat JS. DPOAE in HIV infected adults. Online J Health Allied Scs. 2008, 7(1):9.

26. Ondzotto G, Ibara JR, Mowondabeka P, Galiba J. Cervicofacial and ENT symptoms due to HIV infection in tropical area. About 253 Congolese cases. Bull Soc Pathol Exot. 2004, 97(1):59-63.

27. Campanini A, Marani M, Mastroianni A, Cancellieri C, Vicini C, Human Immunodeficiency virus infection: Personal experience in changes in head and neck manifestation due to recent anti retroviral therapies. Acta Otolaryngol Ital. 2005, 25:30-35.

28. Kelvin CL, Thomas AT. Otolaryngological manifestations of HIV, HIV In Site Knowledge Base Chapter, August. 1998, $1-23$.

29. Bankaitis AE, Keith RW. Audiologic changes associated with HIV- infection. ENT Journal. 1995, 74:353-359. 